\title{
Libraries in the Majority
}

World: A Collaborative Survey Sponsored by Atla and TBN (Theological Book Network) by Maria Stanton Atla

\section{Libraries in the Majority World}

A collaborative survey sponsored by Atla and TBN (Theological Book Network)

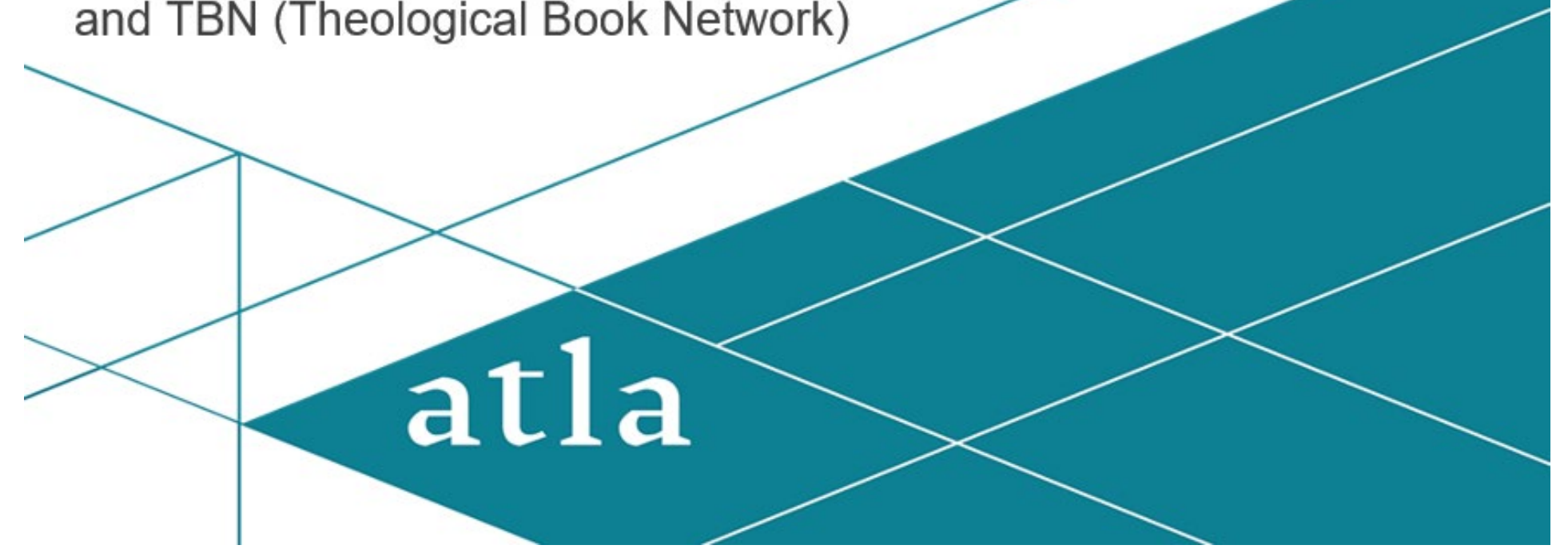




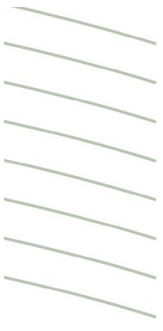

\section{Agenda}

Background \& Goals

vethodology \& Demographics

Vxample Institutions

vigh Level Results

Next steps
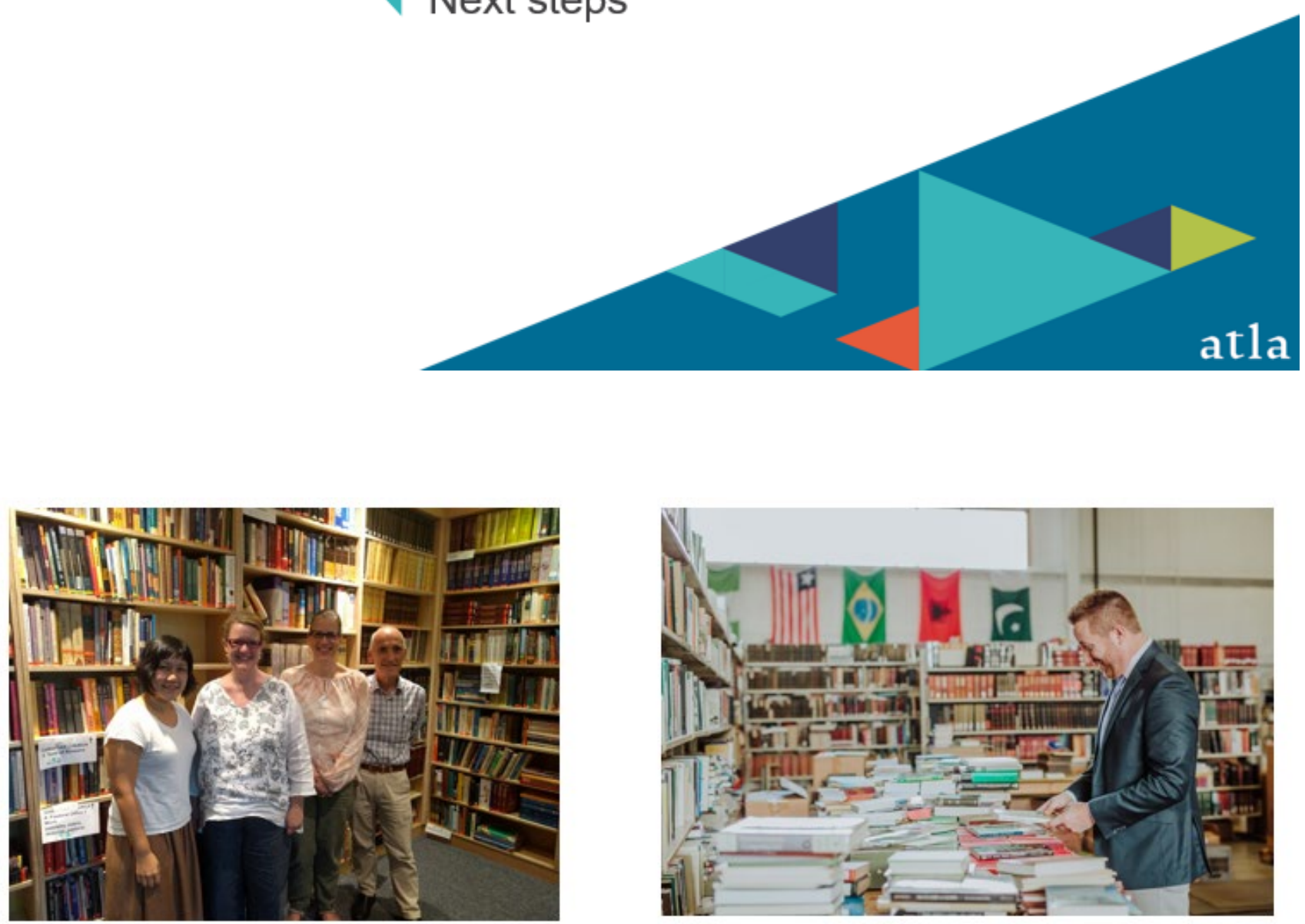

v Atla \& Theological Book Network (TBN) have a long history of collaboration.

v Shared interest in supporting access to high-quality theological resources at underresourced theological schools in Africa, Asia, Oceania, Latin America, Eastern Europe, and the Middle East

Voal: Identify trends \& common needs at the libraries associated with these schools 


\section{Methodology}

\section{Context for the answers}

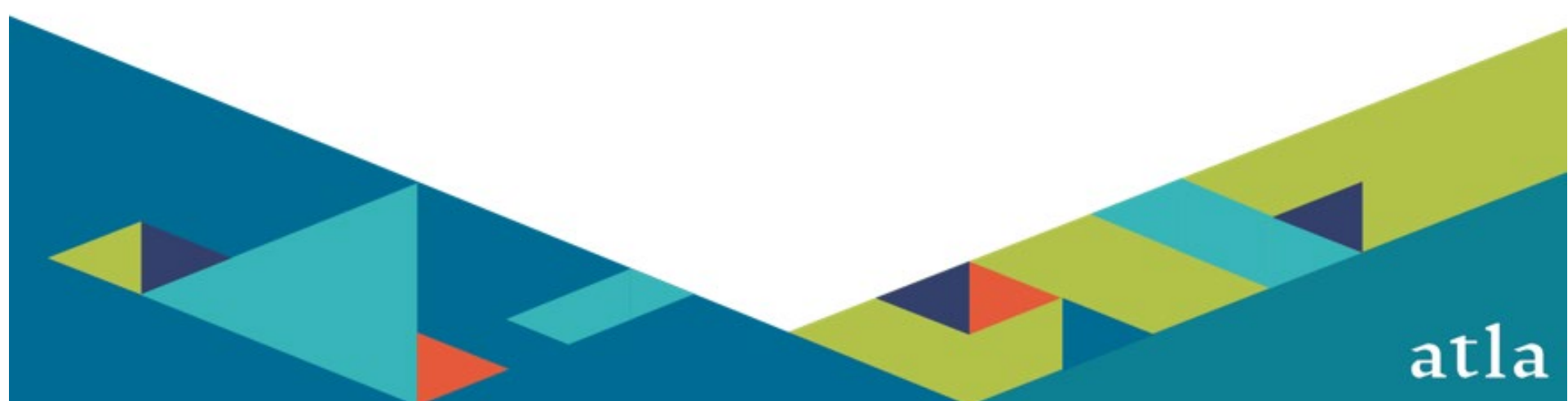

\section{Methodology}

Vnglish-language survey Feb $5^{\text {th }}-$ May $7^{\text {th }} \underline{\underline{2018}}$

Distribution

$\nabla$ Associations such as Association for Christian Theological Education in Africa (ACTEA)

$\nabla$ TBN partner schools

$\nabla \quad$ Listservs / "word of mouth" options

v 60 questions: holdings, technology, staffing, education programs, \& accreditation levels 


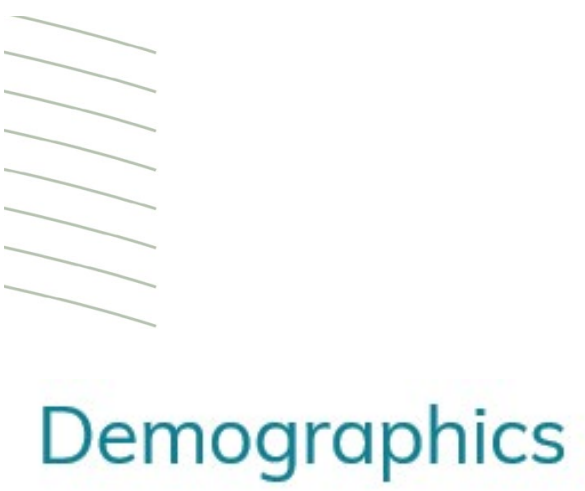

v 228 Institutions

v 47 Countries

v Wide range of Christian denominations

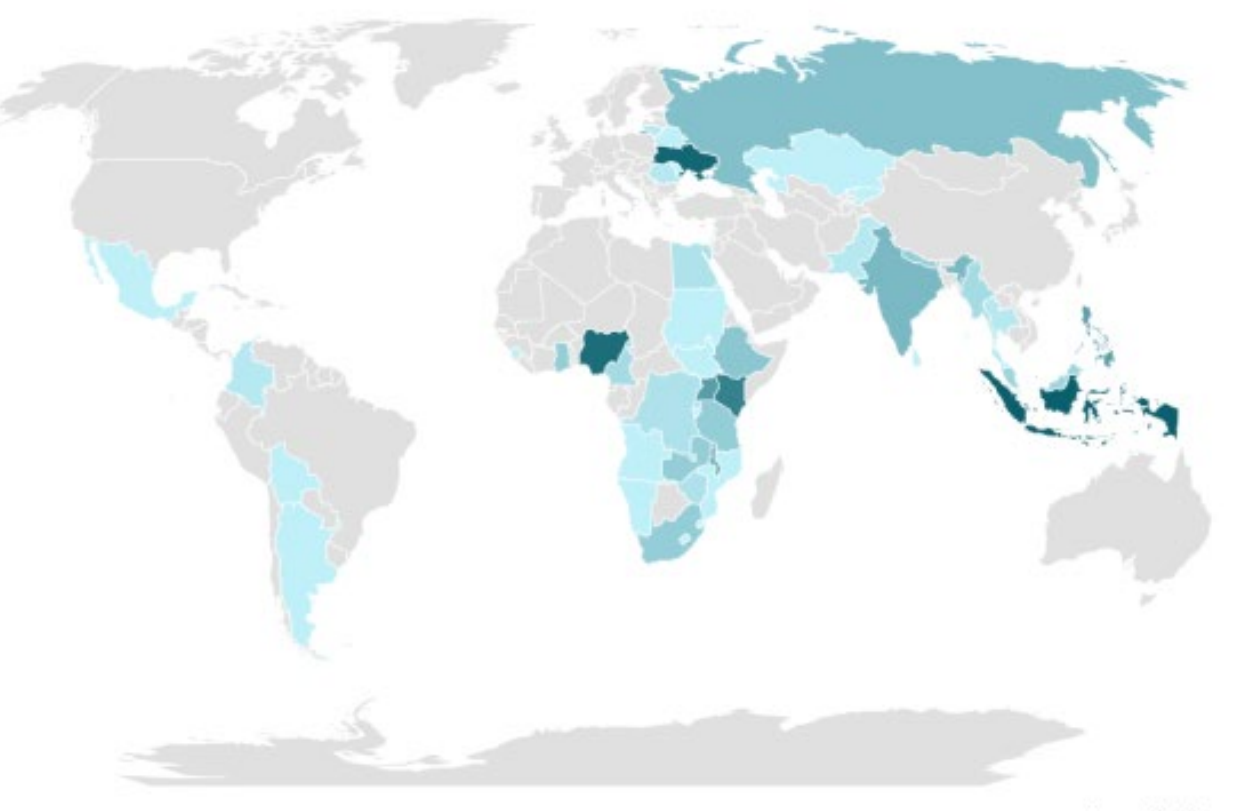

\section{Graduates: Employment}

Areas in which Graduates are Employed ( $\mathrm{N}=197)$

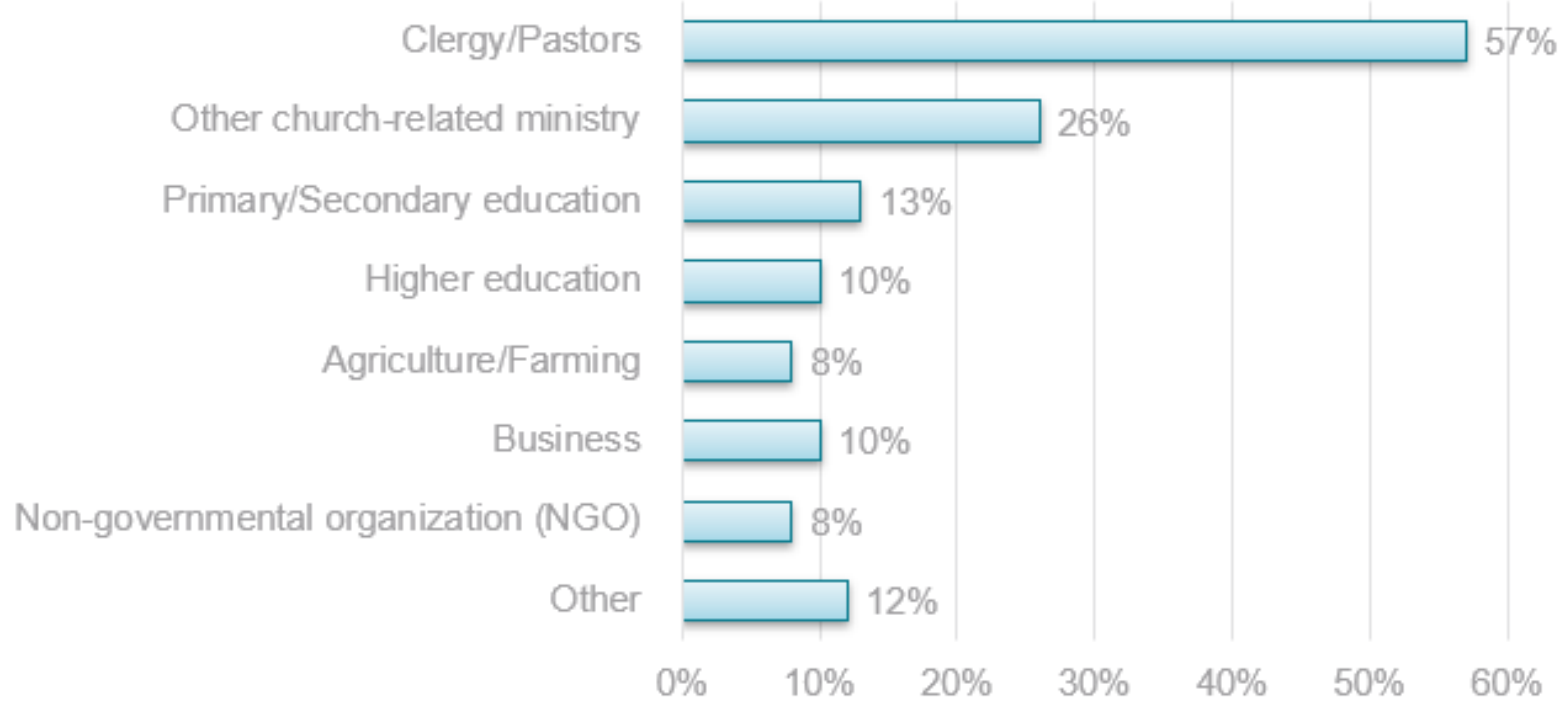




\section{Few more points to provide context}

v Collections

$\nabla \quad 75 \%$ : $<20$ k print books $(26 \%$ have $<5 k$ )

$\checkmark \quad 78 \%:<500$ e-books (38\% have zero)

$\checkmark \quad 73 \%$ : between $0-10$ print journal subscriptions (32\% have zero)

v Staff

$\nabla \quad 40 \%$ : hold title librarian in whole or part

$\nabla \quad 40$ responding libraries have no FT staff

$\nabla \quad 46 \%$ head librarian has formal training (degree)
Vupporting

$\nabla \quad 71 \%: 1-20$ faculty $(41 \%<10)$

$\nabla \quad$ 49\%: 0 - 50 FT Theology students (9\% have no FT students)

$\nabla \quad 31 \%:>100 \mathrm{FT}$ students (most are concentrated in the $101-200$ )

\section{Example Institutions}

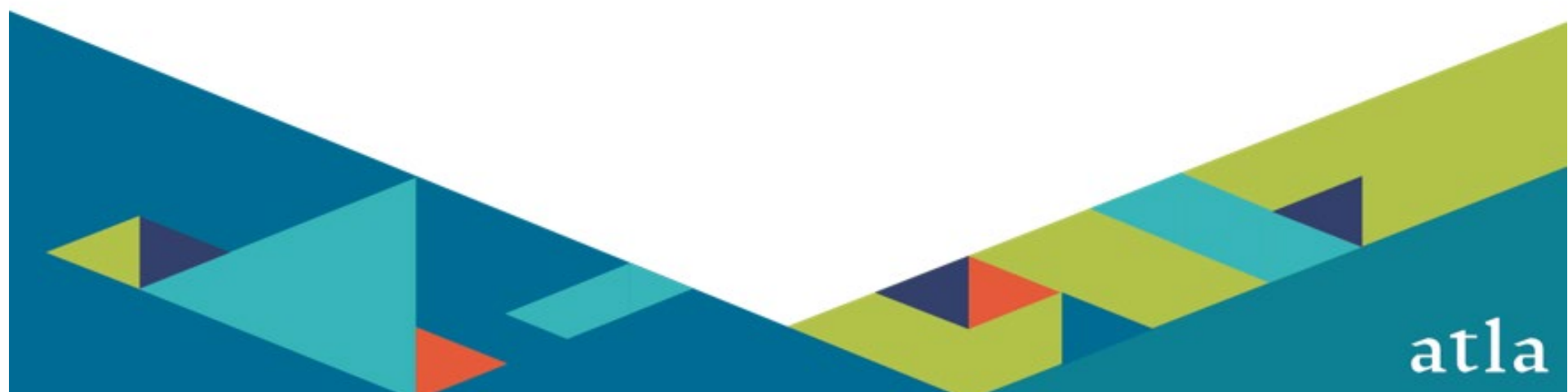




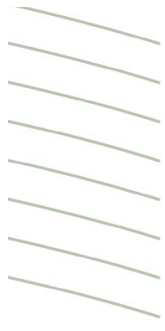

\section{Nepal Bible Baptist College}

Vounded 1998

v 31 students in the Bachelor of Theology

v Also offer an M.Div

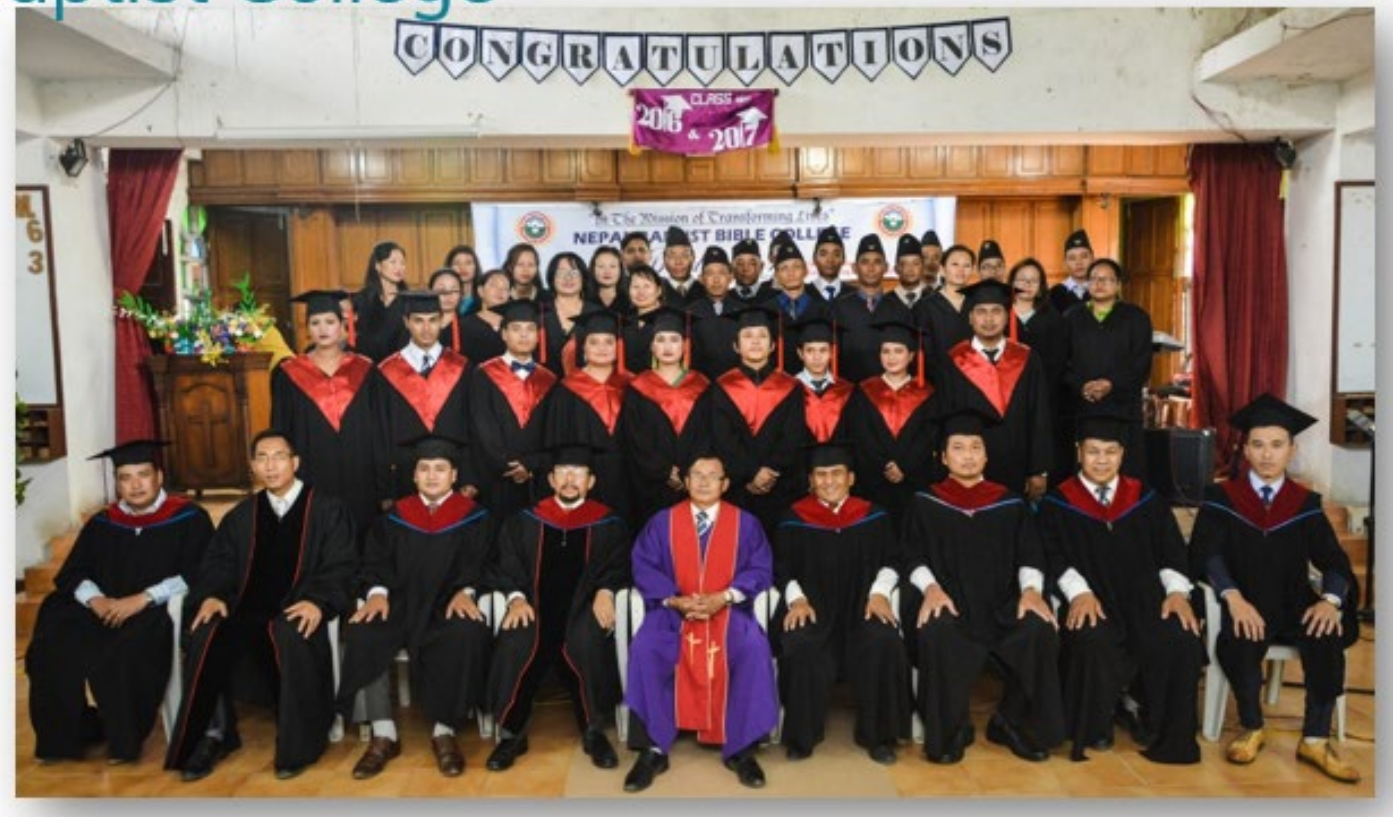

\section{NBBC - Library Page}

v Mina Rai (Librarian)

v Associate / Certificate

No PT library staff

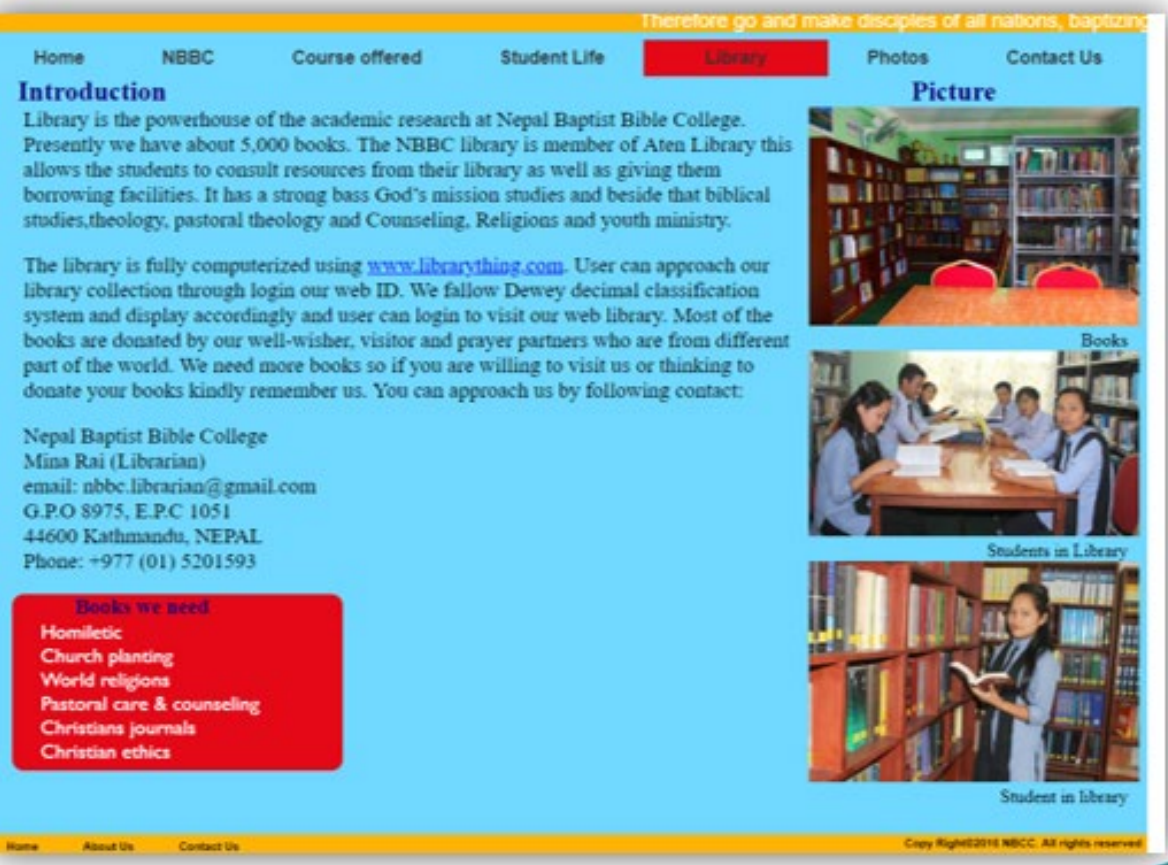




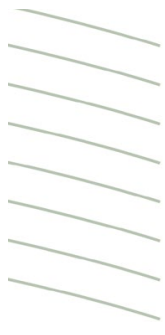

\section{Nepal Evangelical Holiness Theological Seminary}

v Offer-Bachelor of Theology.

v 57 FT Students (114 graduates)

v 14 Faculty

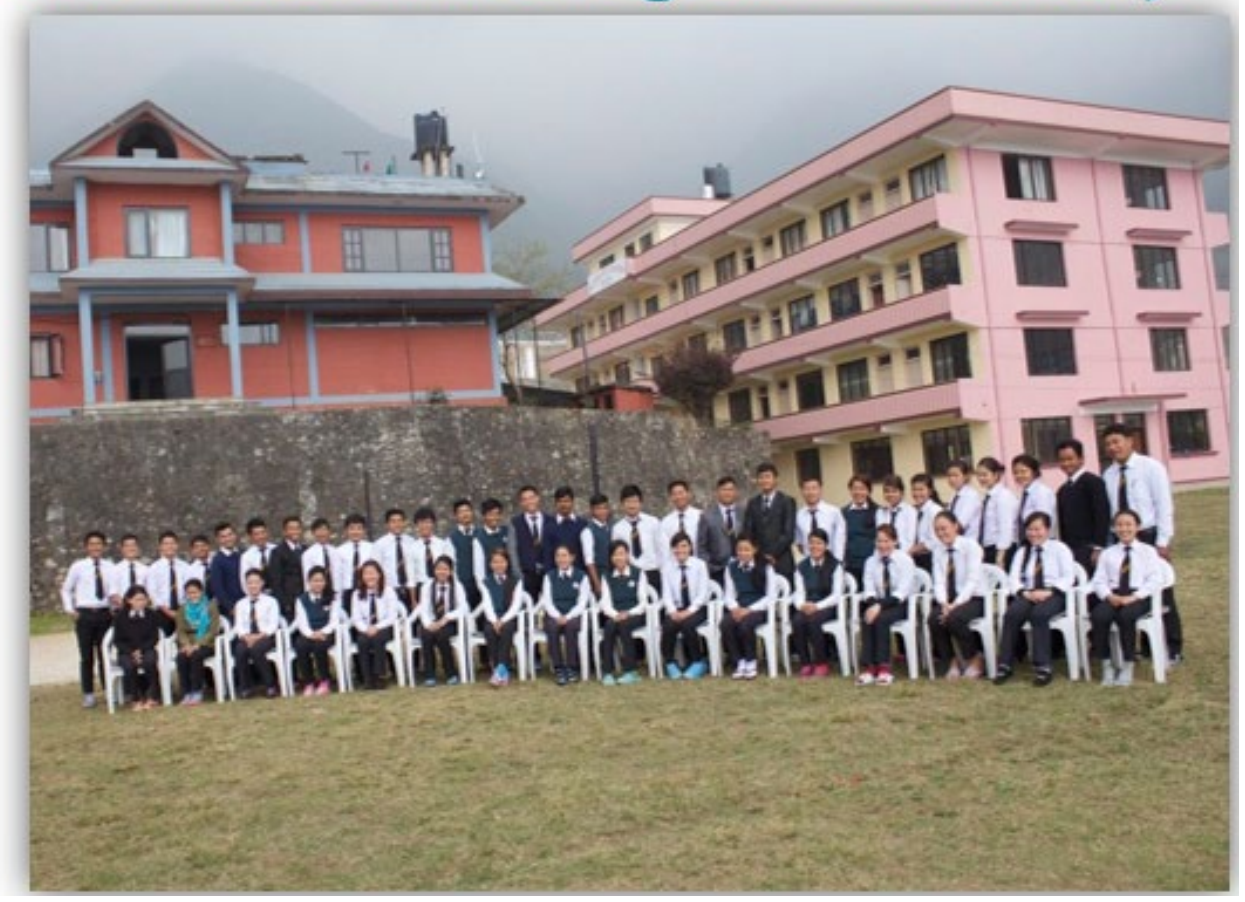

NEHTS Academic Dean Netra Lal Tamrakar

No one who works in the library has formal training

V Cost of internet affects their ability to support students

V Offline Catalogue

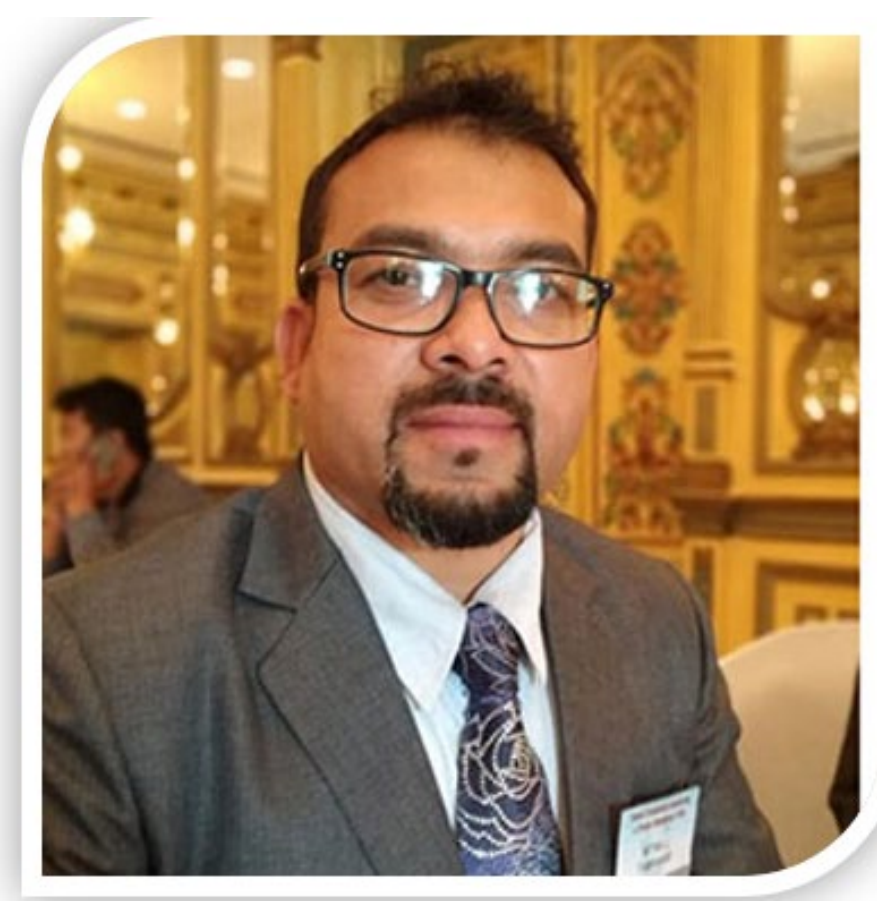




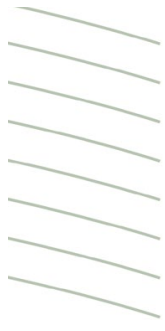

\section{Bangkok Bible Seminary}

v Ms. Sommart Sathian (Librarian Master's)

v Hosted a Library Training Seminar

v 35 faculty

v 688 FT / 100 PT students

v Bachelor of Theology, Master of Biblical Studies, Master of Ministry, Master of Divinity
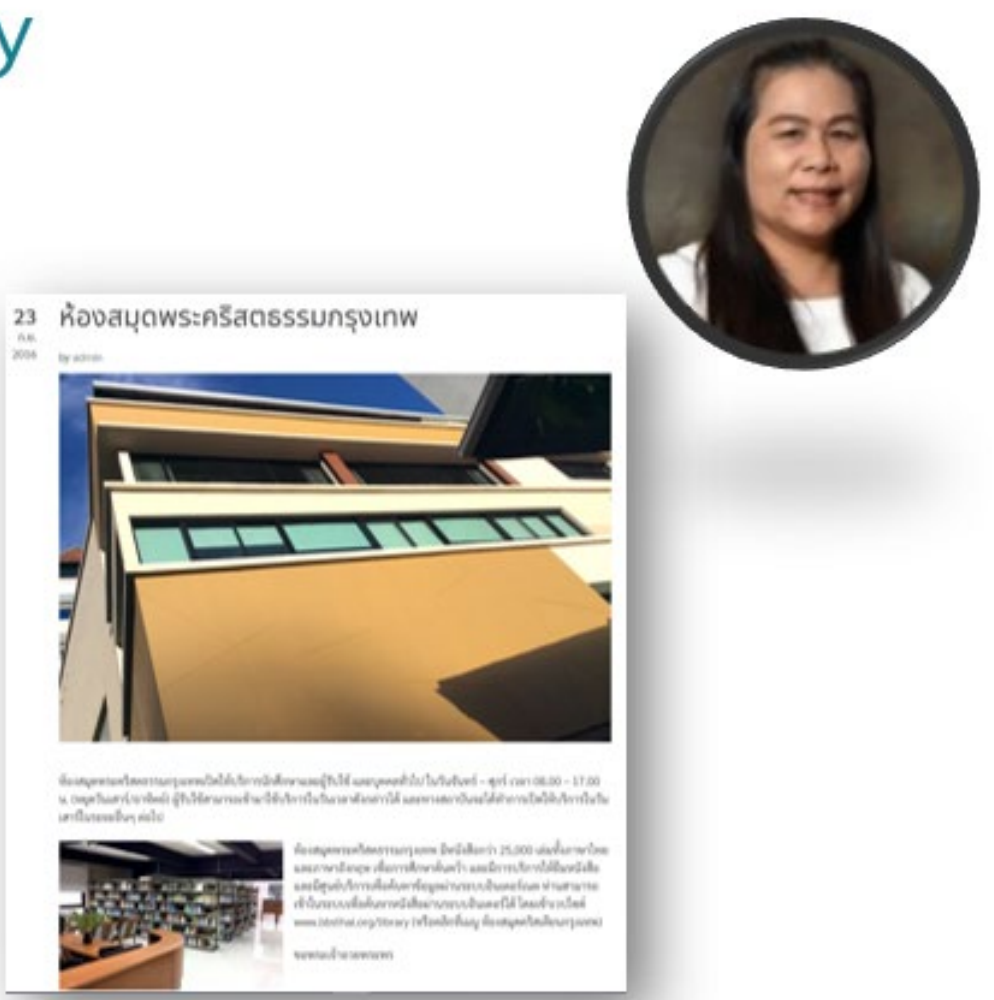

\section{Wolaita Evangelical Seminary (Ethiopia)}

v More than $5 \mathrm{k}$ books

v $220 \mathrm{FT} / 100$ PT students

v 7 FT / 33 PT Faculty

v Print Catalogue

v Bachelor level

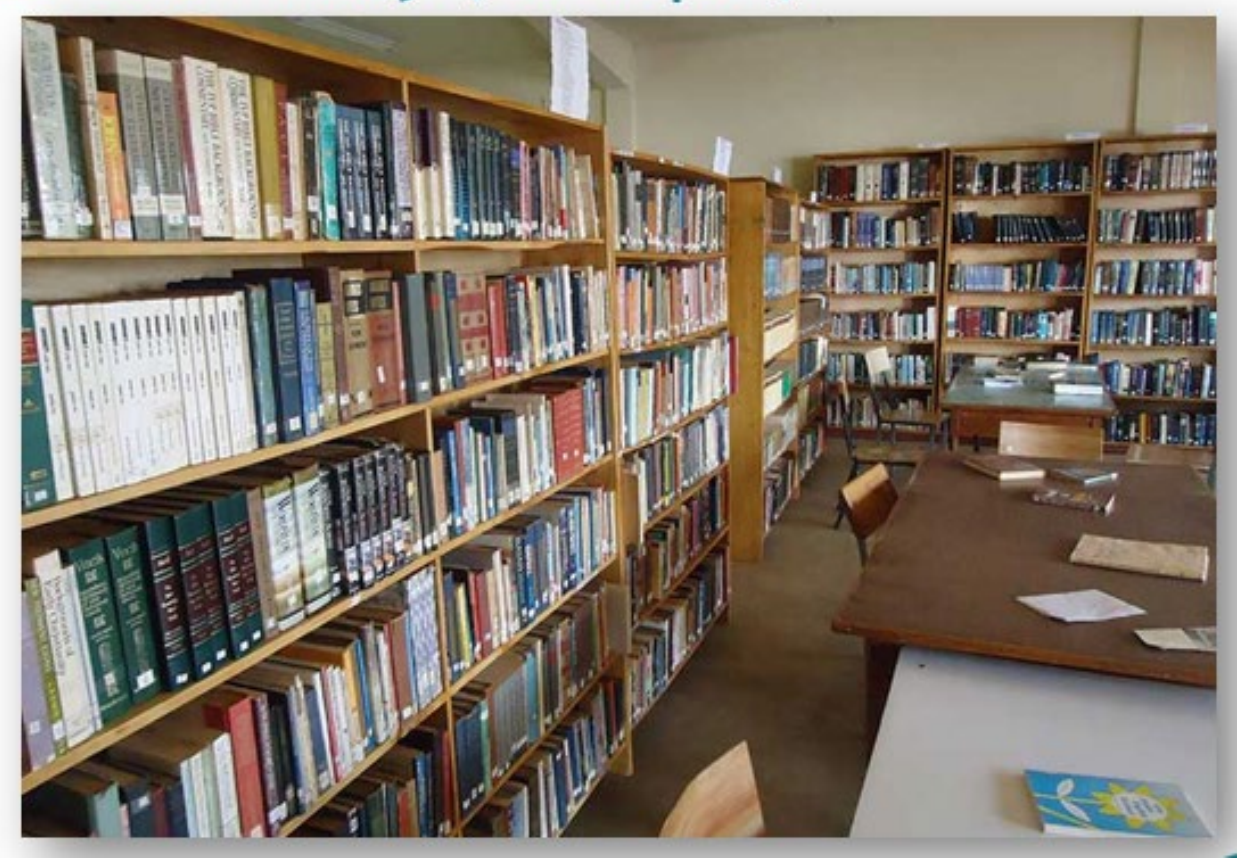




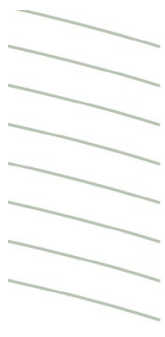

\section{Morija Theological Seminary, Lesotho}

v Herman Dieterlen (Sehoapa) Library

v More than $5 \mathrm{k}$ books

vo FT library staff

v 50 FT students

v 10 Faculty

v Bachelors level program

v Print Catalogue

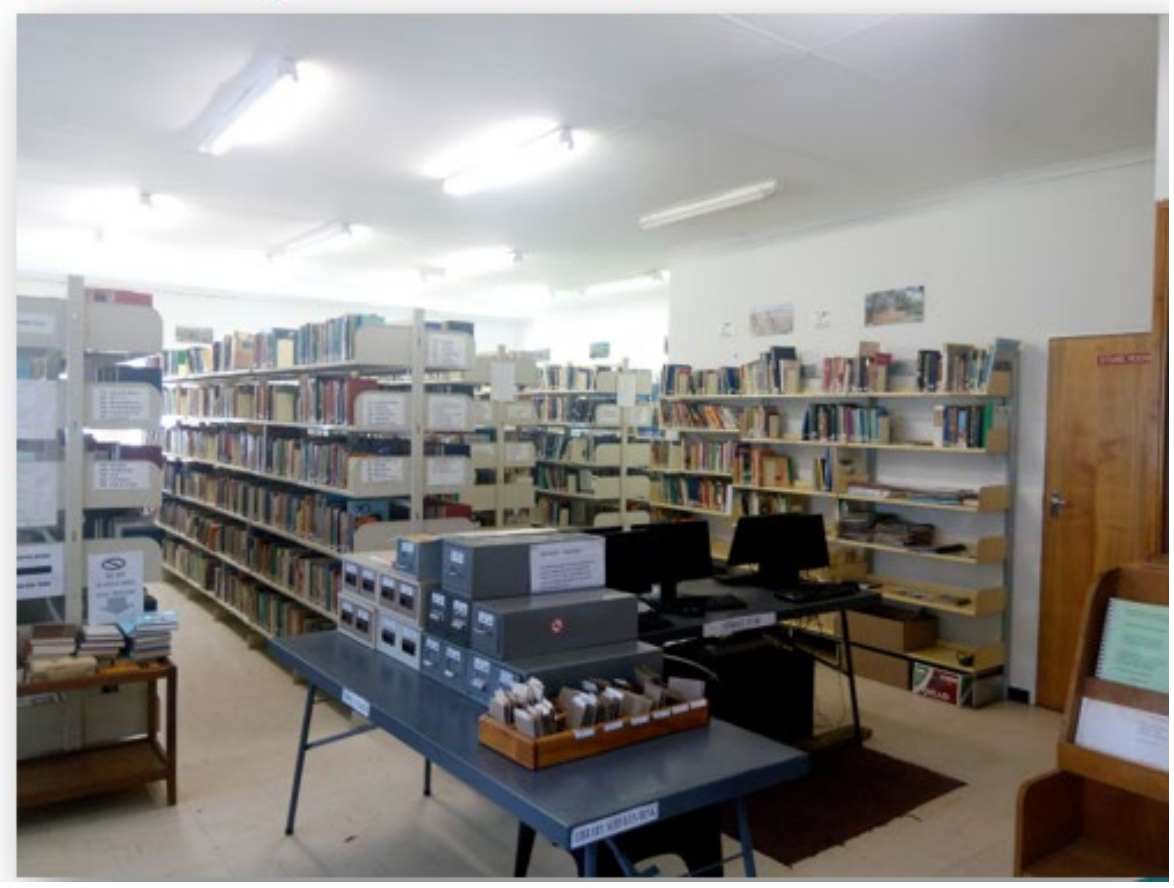

\section{Protestant Institute of Arts \& Social Sciences, Rwanda}

v New Library Building

v Rev. Damien Nzevimana (Dir)

v Masters in Library Science (Moi University, Kenya)

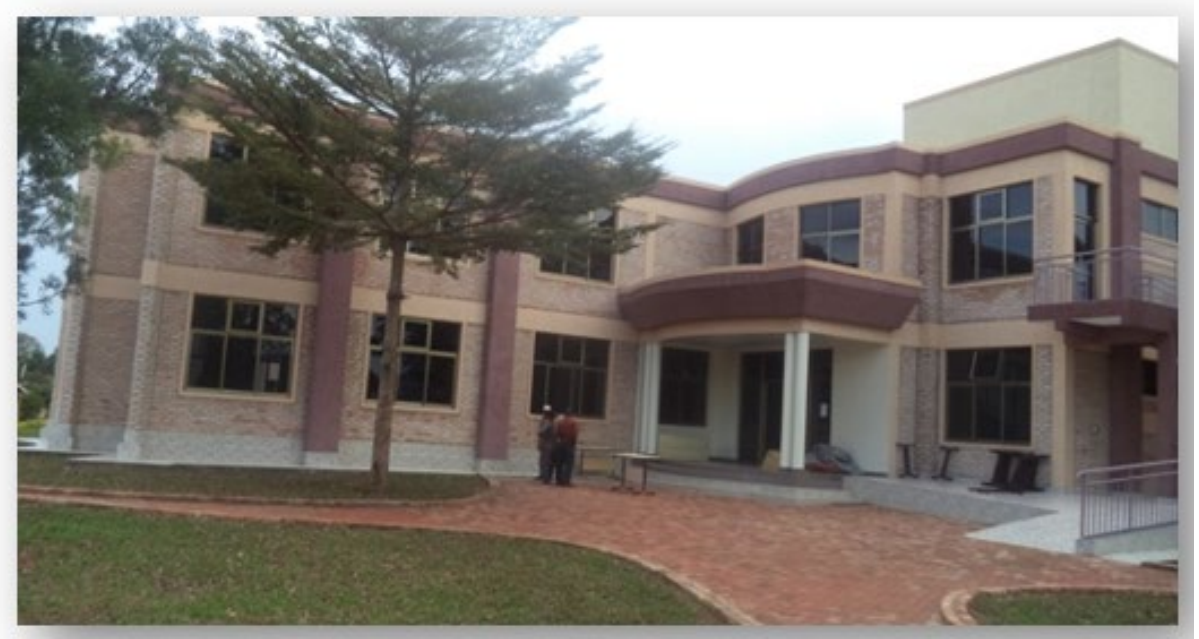




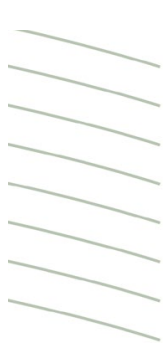

\section{PIASS Library - OPAC}

v Use PMB (3 respondents use this)

v Did not list "Collection

Development / cataloguing" as a top need

V Did list: Reference / Research, Archives, Instruction \& Outreach

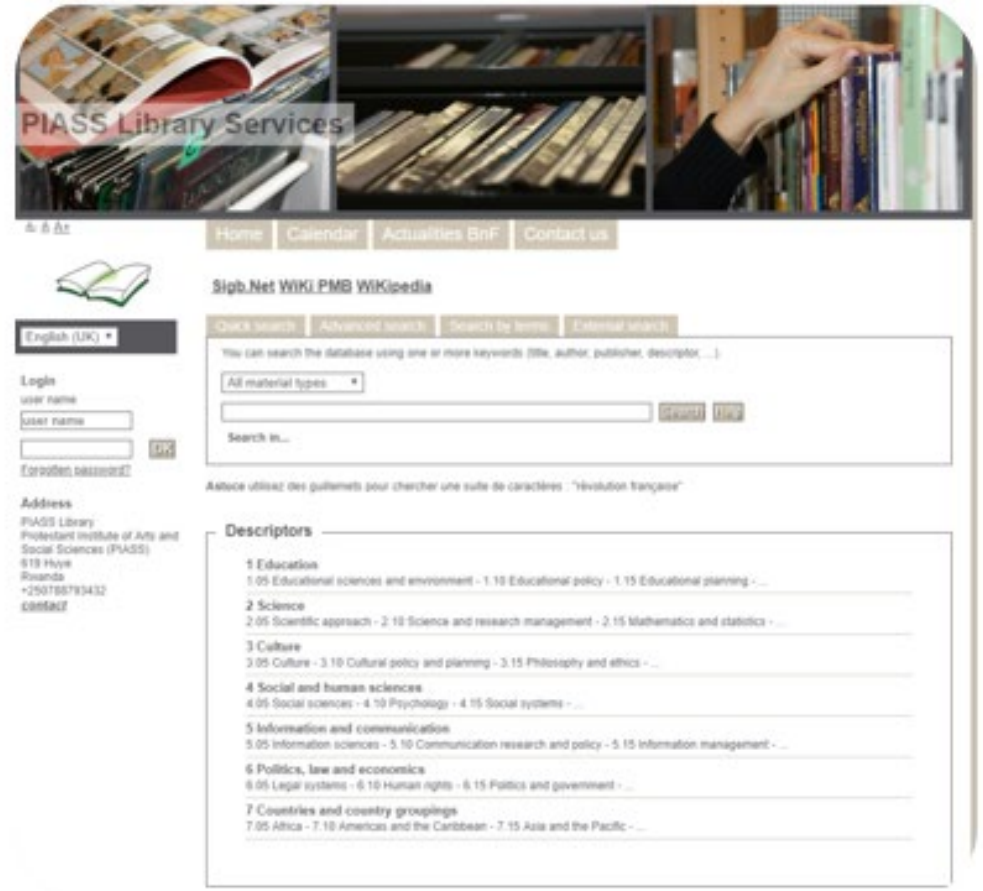

\section{High level Results}

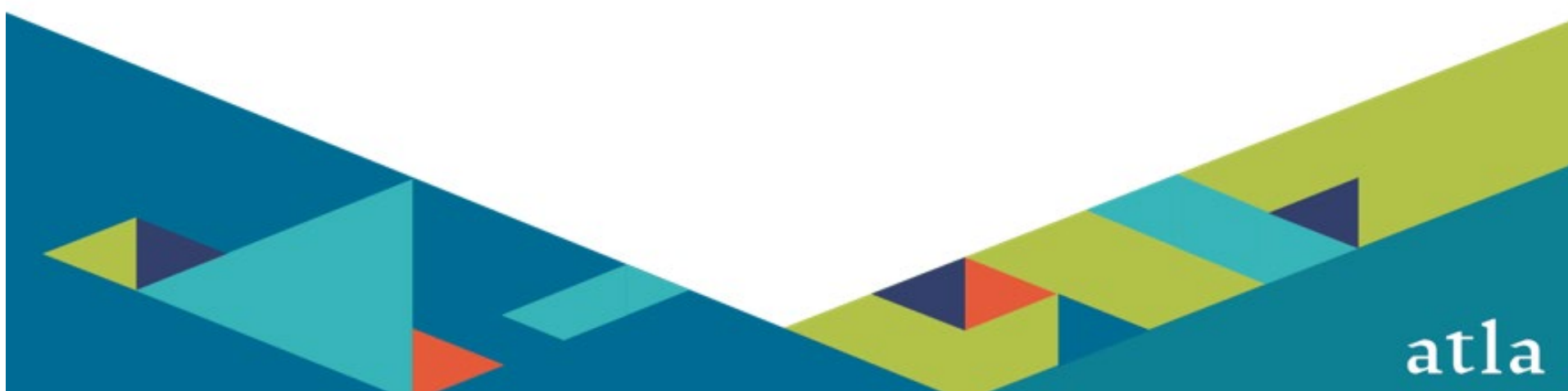




\section{Education Level}

DEGREE LEVELS FOR HEAD LIBRARIANS

$\mathrm{N}=102$

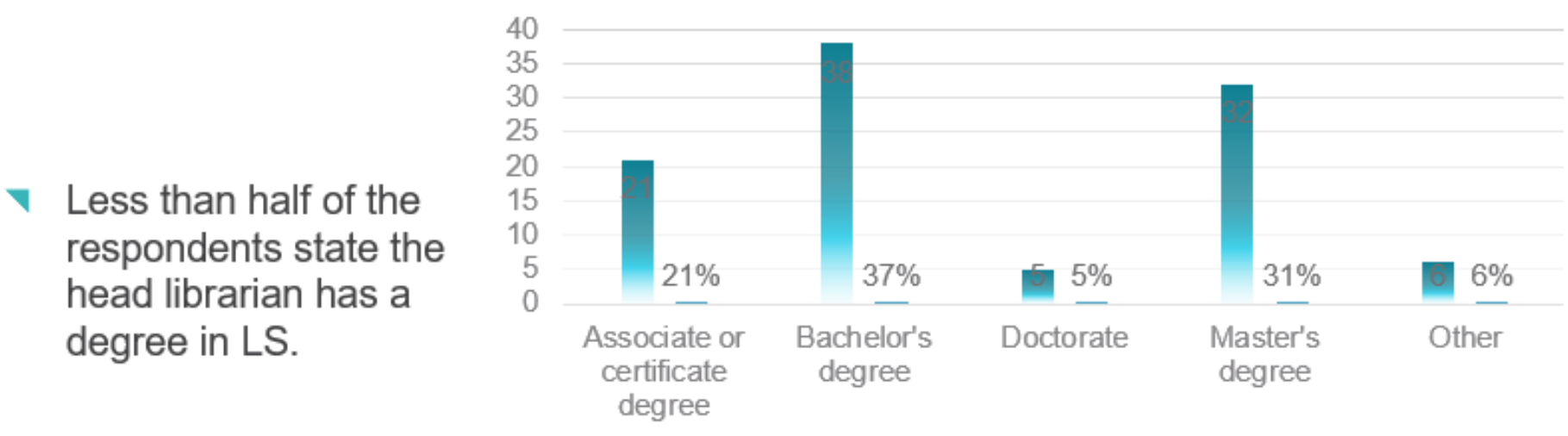

\section{Support \& Training}

Areas where External Support is needed to fulfill Mission \& Goals of the Library $(\mathrm{N}=202)$

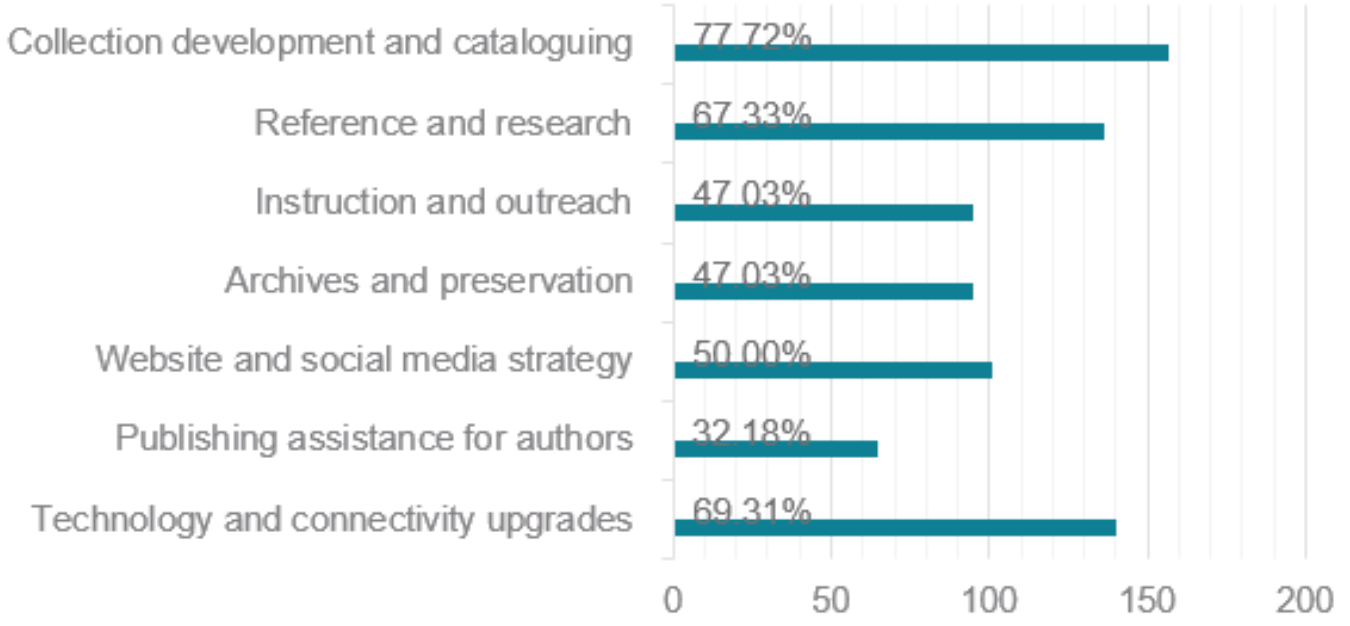




\section{Responses ...}

v Publishing in high impact journals, automated referencing \& plagiarism detection ... (Librarian in Kenya)

v Teach students research skills and how to access electronic information ... (mentioned in one way or another by many)

Very, very much so, skills in digital research, ways of encouraging academic staff to integrate the library into course work ... (Librarian in Malawi)

\section{Technology}

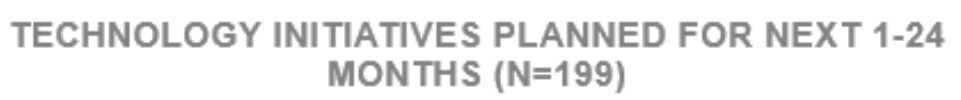

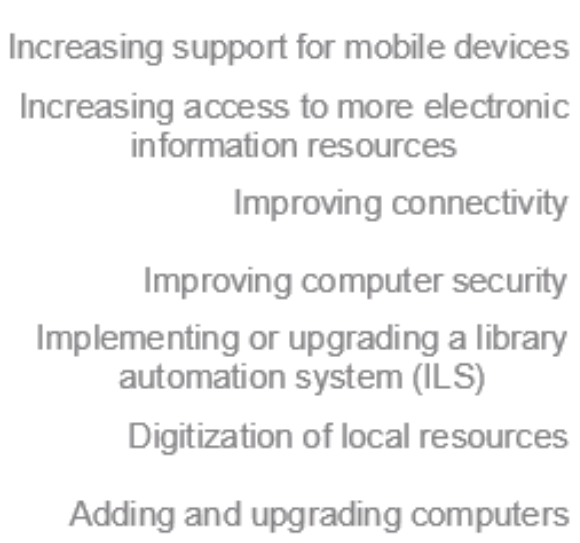

Increasing support for mobile devices Increasing access to more electronic information resources Improving computer security automation system (ILS)

Digitization of local resources

Adding and upgrading computers

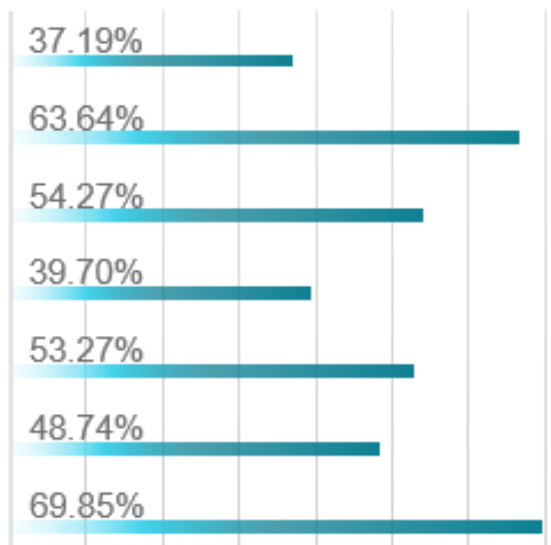

$\begin{array}{lllllllll}0 & 20 & 40 & 60 & 80 & 100 & 120 & 140 & 160\end{array}$ 


\section{Technology}

\section{STUDENT / FACULTY / STAFF WILL RETRIEVE \\ CONTENT IN 5 YEARS $(\mathrm{N}=\mathbf{2 0 3})$}

Virtual/internet access to resources from an international network of libraries and theological schools

Widespread use of mobile devices

Increased electronic access to resources

Much the same as today

\section{$65.02 \%$}

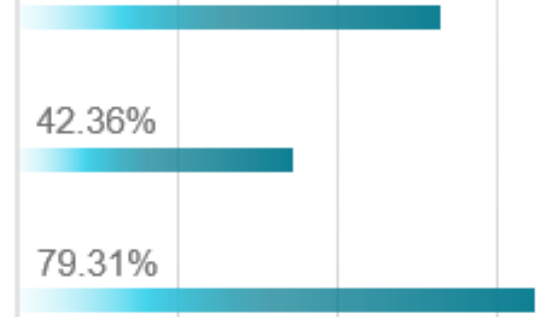

$15.76 \%$

$\begin{array}{llll}0 & 50 & 100 & 150\end{array}$

\section{Publishing / Research}

Does your institution publish scholarly content such as academic journals and books in religion and theology?

\begin{tabular}{|c|c|c|}
\hline YES & $\mathbf{7 1}$ & $\mathbf{3 6 . 0 4 \%}$ \\
\hline NO & 117 & $59.39 \%$ \\
\hline DON'T KNOW & 9 & $4.57 \%$ \\
\hline
\end{tabular}

If yes, what types:

- Journals

- Books, Reference Books, Almanacs, Proceedings

- Multiple Publication Types

- Undetermined Types of Publications 


\section{Summary of Top Challenges}

v Content:

$\nabla$ Academic Resources

$\nabla \quad$ Theological Resources

$\nabla$ Books

$\nabla$ E-Resources

$\nabla \quad$ Up-to-date Materials

$\nabla$ Access
Vtaffing / Staff skills:

$\nabla$ More librarians

$\checkmark$ Digital Library Management

$\nabla$ Library Instruction

$\checkmark$ Professional Development

$\checkmark$ Career potential

\section{We're really not all that different}

Verbatim comments from a question regarding cultural challenges faced by the library:

Vncourage the love \& respect for printed resources

v Students not reading or they just read what the course required

To encourage students and teachers to read more

v Poor library usage

v Many users do not understand the importance of the library 


\section{Resulting Actions}

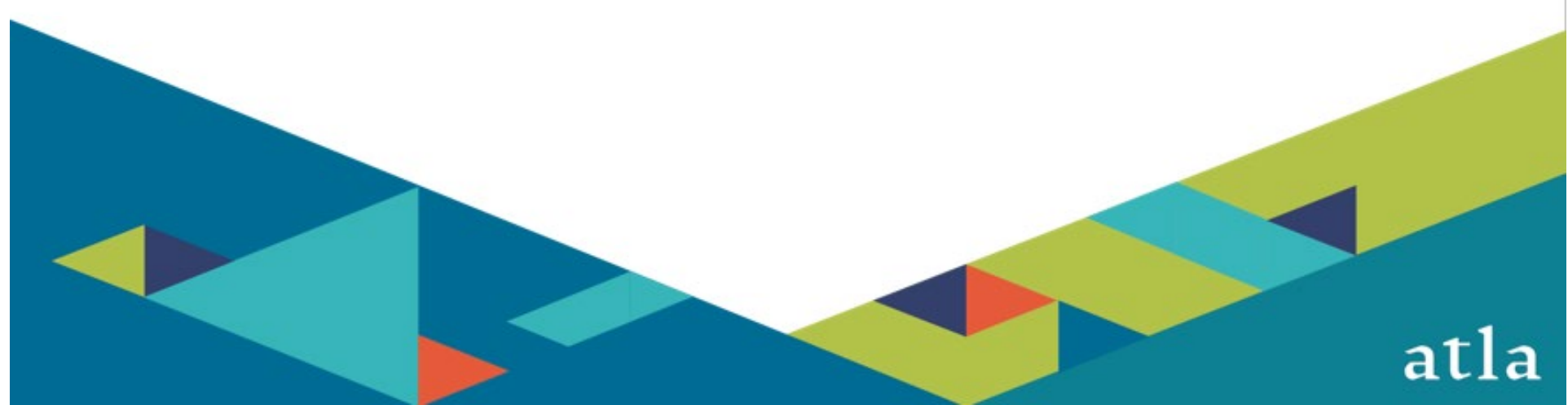

\section{Institutions in Eligible}

Developing Countries

As a not-for-profit association of theological libraries and librarians, Atla understands the importance of supporting theological education throughout the world and has worked to make its products affordable for theological seminaries and schools in eligible developing countries. Atla works with EBSCO to offer institutions in countries designated developing by the World Bank, along with other related criteria, a generous discount on all Atla products and partner products. 


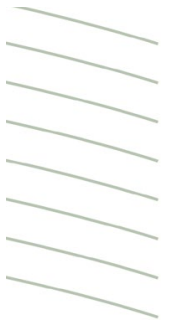

\section{Atla Press: Open Access eBook}

v Updated Edition of A Broadening Conversation

Vey areas

\section{A BROADENING CONVERSATION}

$\nabla$ the character of theological librarianship

$\checkmark$ theological librarians at work,

$\checkmark$ the theological librarian as educator,

$\nabla$ each section is introduced by a present-

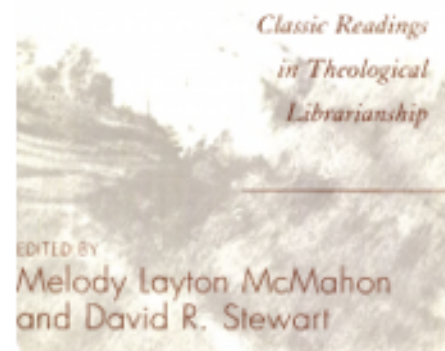
day theological librarian.

\section{International Theological Librarianship Education Task Force (ITLE Task Force)}

v To strengthen and connect theological and religious studies librarians worldwide by identifying resources, creating educational opportunities, and developing skill enhancement materials through collaborative efforts.

v Task Force Members: Kelly Campbell (Columbia Theological Seminary, U.S.) Yasmine Abou-el-Kheir (Chicago Theological Seminary, U.S.) Sandy Ayer (Ambrose University, Canada), Carisse Berryhill (Abilene Christian University, U.S.) Kerrie Burn (Catholic Theological College, Australia) Matina Ćurić (Germany) Seoyoung Kim (World Mission University, U.S.) Griselda Lartey (Columbia Theological Seminary, U.S.) Ephraim Muldave (Africa International University, Kenya) Cynthia Pelena (Central Philippine University, Philippines) Álvaro Pérez (Universidad Bíblica Latinoamericana, Costa Rica) Yesan Sellan (SAIACS, India) Brenda Bailey-Hainer, Staff Liaison 


\section{ITLE Task Force}

v Sponsored the 2019 Atla International Theological Librarian Leadership Institute. A tenday meeting that provided a rich learning experience for international theological librarians. A classroom setting with a cohort (June 10-11), attended the Atla Annual Conference (June 12-15), and visited local libraries (June 16-19).

v The International Theological Librarianship Education Task Force (ITLE Task Force) will be publishing a series of 7 handbooks on theological librarianship as open access monographs. The first volume, which is expected to be published by the end of calendar 2019, is an overview of theological librarianship around the world. Other volumes will cover specific areas of theological librarianship and will be published over the next several years.

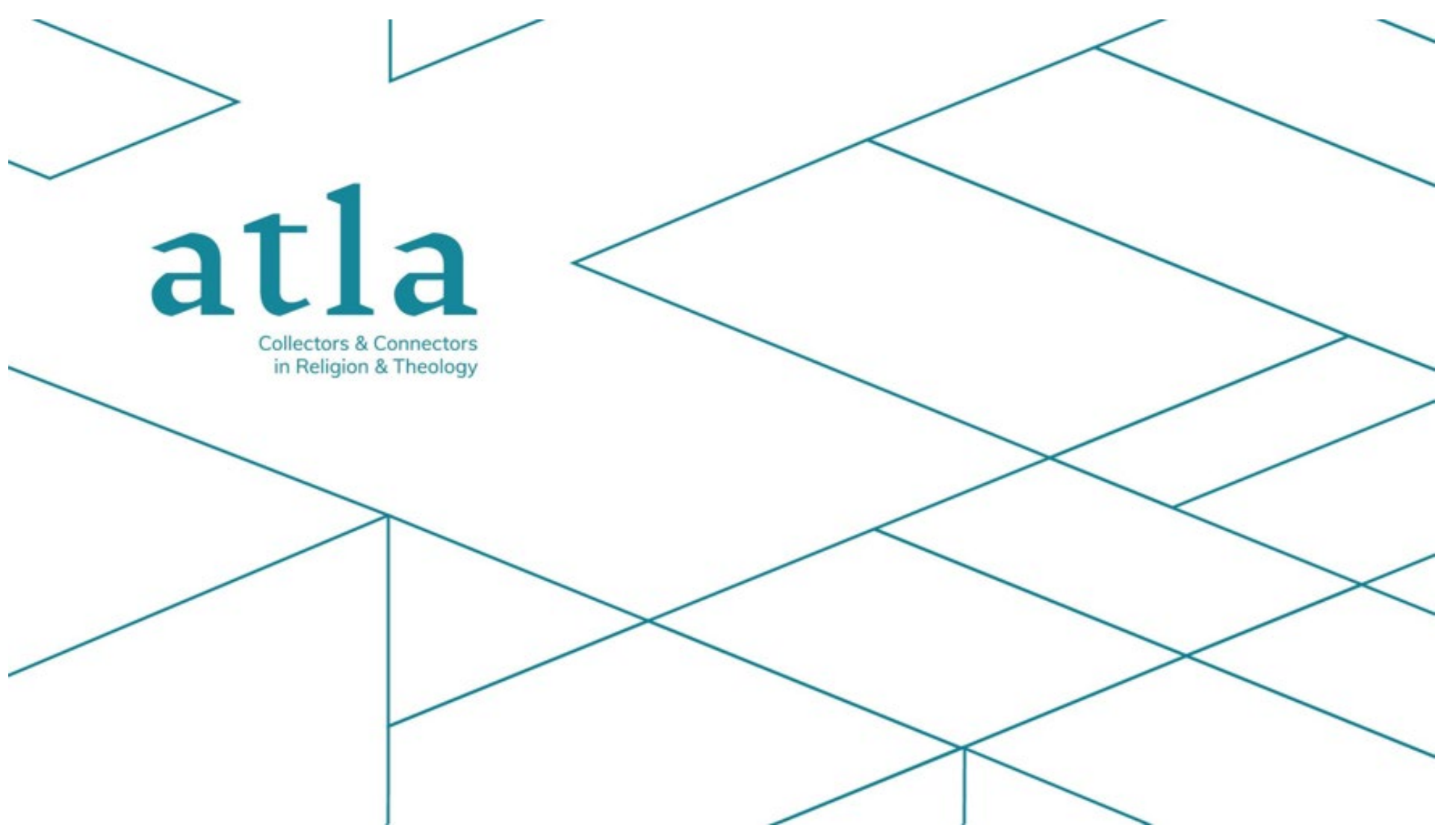

